\title{
KHÔNG GIAN, THÒ̀I GIAN NGHỆ THUẠT TRONG KỊCH BẢN TUỒNG ĐÀO TẤN
}

\section{Art space and art time in the scenario of Dao Tan's Tuong}

\author{
Ngày nhận bài: 12/10/2016; ngày phản biện: 18/10/2016; ngày duyệt đăng:21/11/2016
}

\section{Đinh Thị Kim Thương*}

\section{TÓM TẮT}

Không gian nghệ thuật và thời gian nghệ thuật là một trong những phương thức biểu hiện thế giới qua tác phẩm văn học. Nghiên cứu không gian thời gian nghệ thuật trong kịch bản tuồng Đào Tấn cũng là một cách tiệp cận để giải mã những giá trị văn học trong các tác phẩm của "Hậu Tổ nghề tuồng".

Tù̀ khóa: Không gian nghệ thuật; thời gian nghệ thuật; tuồng Đào Tấn

\begin{abstract}
Art space and art time is one of method to express the world's by literature. Studying art space and art time in Dao Tan's Tuong is also an approach to clarify the literary values of the "posteriori ancestor of Tuong" work.
\end{abstract}

Keywords: Art space; art time; Dao Tan's Tuong

\section{1. Đặt vấn đề}

Không gian và thời gian là một phạm trù triết học chỉ sự tồn tại của thế giới vật chất. Tác phẩm văn học là một thế giới nghệ thuật. Trong thế giới đó, con người tồn tại trong một khoảng không gian và thời gian đặc biệt, đó là không gian nghệ thuật và thời gian nghệ thuật. Nó không chỉ là không gian và thời gian vật chất mà là một phương thức biểu hiện thế giới tinh thần, hiện thực đời sống thông qua tác phẩm văn học.

Là nhà soạn tuồng xuất sắc nhất trong giai đoạn nửa cuối thế kỷ XIX, kịch bản tuồng Đào Tấn đã được nghiên cứu dưới nhiều góc độ khác nhau như: nội dung tư tưởng, kết cấu, ngôn ngũ̃, nhân vật... nhưng vấn đề không gian, thời gian nghệ thuật trong kịch bản tuồng của ông chưa được đề cập đến một cách cụ thể. Ở bài viết này, chúng tôi tiếp cận, nghiên cứu kịch bản tuồng của Đào Tấn bằng lý thuyết không gian, thời gian nghệ thuật của thi pháp học.

\section{Không gian nghệ thuật}

Không gian là môi trường tồn tại của con người: dòng sông, cánh đồng, ngọn núi, đèo xa, biển cả... Không gian là nơi tác giả triển khai sự kiện, biến cố, là chỗ cho nhân vật hoạt động. Không gian có thể tồn tại dưới hai hình thức là không gian vật lý, không gian phi vật lý. Không gian vật lý là không gian chúng ta có thể tri giác được bằng các giác quan như địa điểm, nơi chốn, con người, sự vật... Không gian phi vật lý là không gian con người có thể tri nhận được nhưng không tri giác được bằng các giác quan như: không gian tâm tưởng, không gian tâm linh...

Tuồng là loại hình nghệ thuật tổng hợp bao gồm kịch bản văn học, vũ điệu, âm nhạc, bối cảnh sân khấu, hóa trang, phục trang... trong đó phương thức biểu hiện chủ yếu là ước

\footnotetext{
* Thạc sĩ - Trường Đại học Thủ đô Hà Nội
} 
lệ. Do đó không gian có một vị trí vô cùng quan trọng trong việc chỉ dẫn bối cảnh để cảm thụ tuồng. Đối với tuồng truyền thống với đặc trưng "nội dung cung đình, nhân vật phong kiến”, không gian thường được miêu tả chủ yếu là không gian vật lý gắn với cảnh cung vàng, điện ngọc của triều đình phong kiến là nơi diễn ra hầu hết các sự kiện của truyện. Đó là những Triều Tề (Sơn Hậu), Triều Nguyên (Tam nũ đồ vuoong), Triều đình Cát Thượng Nguyễn (Đào Phi Phụng), Triều Ca (Trầm Hương các)... Trong không gian đó, các mâu thuẫn hình thành và phát triển tạo ra xung đột kịch và phát triển đến cao trào. Không gian thế sự có được nhắc đến nhưng không nhiều và không chi phối chủ đề tư tưởng, nội dung của tác phẩm.

Trong các tuồng bản do Đào Tấn nhuận sắc, về cơ bản các không gian được giữ nguyên như các bản tuồng cổ. Nhưng trong các văn bản tuồng do ông sáng tác, có sự chuyển biến không nhỏ trong cách lựa chọn không gian cho nhân vật xuất hiện. Bên cạnh các không gian truyền thống như cung đình, lầu, phủ, biên ải, đền, miếu... ta thấy sự xuất hiện của những không gian riêng tư như trong khuê phòng (Diễn võ đình, Hộ sinh đàn), tẩm cung (Trầm Hương các); không gian trên đường lưu lạc (không gian hành trình) như trong Diễn võ đình, $H \hat{o}$ sinh đàn, Cổ thành, Tân Dã đồn, Hoàng Phi Hổ quá giới bài quan... Và đặc biệt là sự xuất hiện dày đặc của không gian phi vật lý: không gian tâm tưởng (nhớ mong, hoài niệm, ước mơ...), không gian tâm linh (cõi Phật, cõi tiên, hiện hồn, nằm mộng...).

\subsection{Không gian khuê phòng}

Không gian khuê phòng xuất hiện khá nhiều trong văn học cổ trung đại và thường gắn với hình ảnh người phụ nữ với những khát khao về hạnh phúc lứa đôi. Đó là người vợ nhớ mong chồng trong Khuê oán của Vương Xương Linh hay Chinh phụ ngâm của Đặng Trần Côn (Đoàn Thị Điểm diễn Nôm), sự khát khao hạnh phúc của Thúy Kiều khi gặp Kim Trọng và sự bẽ bàng của nàng khi ở lầu Ngưng Bích (Truyện Kiều - Nguyễn Du), đó còn nỗi đau ai oán khi mất vợ trong Khuê ai lục (Ngô Thì Sĩ) và Văn tế Truoong Quỳnh Nhu (Phạm Thái)...

Trong tuồng của Đào Tấn, không gian khuê phòng được sử dụng như bối cảnh để tâm sự, tự tình và giao duyên. Đó là khuê phòng của Vương Kiều Quang nơi nàng cùng Bích Đào (Triệu Khánh Sanh) sớm tối học thêu thùa và tâm sự chuyện nữ nhi. Ở nơi đó ấp ủ ước mơ hạnh phúc của Kiều Quang và những tâm sự băn khoăn của nàng về một người thị nữ với "hành vi lạ lùng". Đồng thời đó cũng là nơi "nương mình" của Triệu Khánh Sanh trong vai Bích Đào với lòng bi hận khôn cùng trước thời cuộc đảo điên"Kham thán thời vận chi điên đảo/Ta hồ tình thế chi quai vi" (Xót bấy vận thời điên đảo/Đau vì tình thế rối ren) và đó cũng là nơi nuôi dưỡng tình yêu của chàng và nàng qua từng đường kim, mũi chỉ:

Bích Đào (Khánh Sanh): ... chắp tơ mành

Kiều Quang: ... dóng thẳng đường ngay

Bích Đào:... nhận nẻo quanh

Kiều Quang: Cúc trắng, mai vàng thưa thót nhụy

Bích Đào: Chim xanh lá đỏ ngẩn ngo tình

Cùng ngâm: Uyên wơng chếch bạn còn lo láo

Phỉ thúy chiều duyên khéo rập rình

Từng lời thơ xoắn xuýt nhau đầy quyến luyến, đầy yêu nhưng mang những tâm trạng khác nhau. Kiều Quang lúc này chưa biết Bích Đào là Khánh Sanh, nàng gửi yêu thương vào mộng tưởng về một hình bóng tình lang không biết đang lưu lạc phương nào. Còn Khánh Sanh trong khung cảnh uyên ương này không kìm chế nổi những cơn sóng tình đang cuồn 
cuộn trong lòng muốn ôm chặt Kiều Quang vào lòng cho thỏa niềm khao khát:

Truoóc chura họ xem qua lăng líu

Nay học rồi ngẫm lại lí lăng

Cắc cớ thay dì gió chị trăng

Thày lay bấy mũi kim đường chỉ

Cảnh học thêu của Kiều Quang - Khánh Sanh trong khuê phòng có lẽ là khung cảnh tình yêu đẹp nhất trên sân khấu tuồng bởi lẽ sân khấu cung đình phong kiến thường chỉ dành cho đề tài quân quốc hiếm có chỗ cho những tình cảm cá nhân, đặc biệt là tình yêu nam nữ. Vậy mà, không chỉ một lần cảnh ân ái riêng tư của lứa đôi được Đào Tấn đưa lên sân khấu tuồng. Mặc dù giữa chốn cung đình nhưng tẩm cung của Đát Kỷ lại được Đào Tấn khắc họa là một không gian sinh hoạt đời thường của cuộc sống vợ chồng. Ở đó không còn vua, không còn phi, không còn lễ giáo hà khắc mà chỉ có những hành động quan tâm chăm sóc rất đỗi bình thường của người chồng dành cho vợ:

Đát Kỷ: Trong mình lạnh, mà trạo trụcc trong cổ nũa. Lại trống ngực đánh hoài khó chịu lắm. Xin quốc trưởng, ngài vuốt cho tôi một tí nào!

Vua Trụ: Để quả nhân vuốt cho. Xuôi, xuôi, xuôi, xuôi!

Đát Kỷ: Chao ơi, mỏi xương sống lắm, hãy đấm cho tôi một tí!

Vua Trụ: Ù', để quả nhân đấm cho...

Đát Kỷ: Chao ôi! Nóng mặt lắm, biểu đứa mô hắn quạt phất pho cho dễ chịu.

Vua Trụ: Đúa nào quạt bay!

Đát Kỷ: Thôi... ô i lạnh lắm!

Vua Trụ: Bay quạt mạnh lắm, răng mà quân hu lắm. Để tao quạt cho bay coi coi.

(Quạt) Thôi đùng rên nũa mà mệt...
Trong Hộ sinh đàn, không gian khuê phòng còn là nơi tự tình, bày tỏ tâm trạng của người phụ nữ khi chồng đi xa:

Luống thâm khuê vĩnh dạ ưu sầu

Hà! Khéo loi thoi duoong liễu mạn đầu

Càng thanh thót hoàng oanh chi thuợng

Một mình nơi khuê phòng, Lan Anh bày tỏ sự cô đơn, thấp thỏm và nỗi ngóng mong chồng trở sau bao ngày xa cách. Vế đầu mượn tứ thơ trong bài "Khuê oán" của Vương Xương Linh, vế sau mượn lời bài "Xuân oán" của Kim Xương Tự, Đào Tấn đã khắc họa sâu sắc nỗi buồn, cô đơn và sự tủi thân, ai oán trong lòng người thiếu phụ:

\section{Khuê oán}

Khuê trung thiếu phu bất tri sầu

Xuân nhật ngung trang thwớng thúy lâu

Hốt kiếm mạch đầu duong liễu sắc

Hối giao phu tế tịch phong hầu

(Vợ trẻ buồng thêu chẳng biết sầu

Ngày xuân trang điểm bước lên lầu

Chợt thấy đầu đường phơi sắc liễu

Tại ai giục giã chuyện phong hầu)

\section{Xuân oán}

Đả khởi hoàng oanh nhi

Mạc giao chi thượng đề

Đề thời kinh thiếp mộng

Bất đắc đáo liêu tê (tây)

(Xua đi cái oanh vàng

Trên cành cấm hót vang

Hót làm thiếp tỉnh mộng

Liêu tây chẳng gặp chàng

Trong hoàn cảnh này, Lan Anh tự ví mình như người thiếu phụ trong "Khuê oán" và "Xuân oán”, ngày ngày mong nhớ lang quân nhưng tỉnh dậy chỉ thấy bẽ bàng đơn chiếc một 
mình. Nàng cũng như những thiếu phụ ấy khát khao có được cuộc sống bình yên bên người mình thương yêu nhưng đối mặt với sự thật phũ phàng luôn là bi kịch chia ly xa cách. Tương phản với những chủ đề lớn lao kỳ vỹ trong tuồng cổ, Đào Tấn đã thực sự tinh tế, nhân văn khi đưa không gian khuê phòng cùng ước mơ của người phụ nữ lên sân khấu tuồng.

\subsection{Không gian hành trình}

Không gian hành trình là không gian có sự chuyển biến liên tục, thể hiện sự di chuyển của nhân vật từ nơi này sang nơi khác. Gắn với mô típ truy đuổi - chốn chạy và mô típ tha hương, trong tuồng của Đào Tấn xuất hiện khá nhiều không gian hành trình. Đó là cuộc đuổi bắt của Bàng Hồng với Triệu Khánh Sanh (Diễn Võ đình), Võ Tam Tư với Tiết Cương (Hộ sinh đàn); Đó là sự di chuyển của Triệu Khánh Sanh trên đường tha hương, Tiết Cương, Lan Anh lưu lạc trong rừng, Hoàng phi Hổ trên con đường quá ải "phản trụ, đầu chu", Quan Công qua 5 ải chém 6 tướng hồi Cổ thành, Từ Thứ trên đường tiễn biệt anh em Lưu, Quan, Trương qui Tào cứu mẹ...

Không gian hành trình thường được miêu tả qua không gian rừng núi, quan ải và không gian trên đường cô chinh.

Không gian rừng núi thường gợi lên cảm giác hùng vĩ, bí ẩn và chứa đựng sự nguy hiểm. Chúng ta vẫn có câu "non cao rừng thẳm", "rừng thiêng nước độc" để hình dung địa thế của loại không gian này. Các nhân vật chính diện thường bị đặt trong hoàn cảnh lạc giữa rừng sâu như một thử thách để thể hiện bản lĩnh, sự dũng cảm, anh hùng. Bằng tài năng, trí dũng hoặc được sự giúp đỡ của các nhân vật tâm linh, nhân vật chính sẽ vượt qua thử thách này để đến với thành công và hạnh phúc. Trong Son Hậu, Kim Lân cùng Thứ Phi bị lạc giữa rừng, chàng được hồn Khương Linh Tá biến thành ngọn đuốc soi đường băng rừng vượt núi đến thành Sơn Hậu. Đào Phi Phụng bị truy sát lạc trong rừng gặp miếu Quan Công và được Quan Công giúp thay đổi hình dáng thành Lý Vạn Chung trà trộn vào triều đình Cát Thượng Nguyên báo thù. Vợ chồng Lan Anh - Tiết Cương hai lần lạc nhau trong rừng, lần thứ nhất Lan Anh một mình đi tìm chồng trong tình cảnh "lấm lê lấm lết", nhờ mưu trí, gan dạ mà nàng cứu được chồng đưa về Long Sơn trại; lần thứ hai bị tập kích ở Long Sơn trại, nàng cùng Hồ Nô lạc trong rừng sâu lại đúng lúc trở dạ sinh con, nhờ có sự giúp đỡ của thần Hộ thai nên mẹ tròn con vuông, tay ôm con, tay bế cháu đi tìm chồng. Nhờ có tổ tiên họ Tiết phù hộ, hai vợ chồng đã gặp lại nhau và trở về sơn trại sống hạnh phúc. Như vậy, có thể thấy, không gian rừng núi trong tuồng bản của Đào Tấn mang ý nghĩa như sự thử thách dành cho các nhân vật chính. Đó là một trong chuỗi các không gian hành trình tương ứng với chuỗi các thử thách mà nhân vật phải vượt qua để đi đến thắng lợi cuối cùng.

Không gian quan ải khiến ta hình dung đến những ranh giới mà con người phải vượt qua để đến một đích nào đó. Quan ải cũng gắn với hình ảnh chiến trận, những đội quân chinh chiến liên miên, sự tang tóc và bi thương... Cũng như không gian rừng núi, không gian quan ải cũng là một trong những thử thách mà nhân vật phải vượt qua để khẳng định mình. Muốn đến Cổ thành, Quan Công phải vượt qua 5 cửa ải, chém 6 tướng; Muốn qua ải Giới bài để “đầu Chu”, Hoàng Phi Hổ cũng phải vượt qua ải Trần Thương, Trần Ngô và biên ải do chính cha mình (Hoàng Cổn) trấn giữ; Muốn đánh quân Tào Nhân, Quan Công phải chiếm được Phàn Thành; Muốn đánh đổ lũ phản nghịch họ Tạ, Đổng Kim Lân, Phàn Diệm phải náu mình tại Sơn Hậu dưỡng quân suốt 15 năm; Đào Phi Phụng và quân Cát Thượng Lân giao tranh ngoài biên ải. Không gian quan ải 
cũng là không gian cho những cuộc chia ly: Đó là cuộc chia ly của anh em Lưu, Quan, Trương tiễn Từ Thứ quy Tào, Đổng Mẫu Kim Lân; Đào Công - Nguyệt Tâm phải lựa chọn giữa trung và hiếu... (thử thách cả về tâm lý và lòng dũng cảm).

Không gian trên đường cô chinh thường là không gian lẻ loi một mình. Không gian này được Đào Tấn khắc họa bằng những hình ảnh ước lệ thể hiện không gian rộng lớn cô liêu đối lập với sự nhỏ bé của con người như "sơn nhai hải giác" (đầu non góc bể), "góc bể chân trời", "thiên cao địa hậu” (trời cao đất dày); gắn với những tình cảnh của con người trên đường cô chinh như "Nam Hồ Bắc Việt" (nay đây mai đó), "Sông Sở non Ngô" (xa cách), "khứ quốc ly gia" (bỏ nước, lìa nhà). Khung cảnh trên đường đi thường được miêu tả hoang vu, quạnh quẽ và đơn độc với các hình ảnh : "nhạn quy thanh", "tàn nguyệt", "thiên lý”, "lữ điếm", "hương đài nhất vọng", "dấu thỏ đường dê", "tiếng viên điểu”... và sự ảm ảnh bởi tương lai mịt mờ phía trước với hình ảnh : "lộ nan” (đường đi khó), "lộ đa kỳ" (nhiều đường phía trước không biết nên đi đường nào).

Không gian trên đường cô chinh cùng với không gian quan ải và không gian rừng núi tạo nên một bức tranh tổng thể về hành trình của nhân vật trong toàn bộ tác phẩm. Đó là không gian chính để nhân vật bộc lộ mình và thể hiện tư tưởng chủ đề của tác phẩm.

\subsection{Không gian tâm tưởng và không gian tâm linh}

Không gian vật lý không phải là cõi không gian duy nhất của vũ trụ. Cao hơn không gian vật lý còn có không gian tâm tưởng và không gian tâm linh với sự chi phối bởi những quy luật tâm lý, tình cảm và trí tưởng tượng phong phú của con người.

Không gian tâm tưởng được qui định bởi sự tác động tích cực của tình cảm lên tư duy và sự trỗi dậy mạnh mẽ tiềm thức khiến con người sinh ra những ảo giác hoặc chìm đắm trong những dòng suy tưởng về quá khứ hay sự kỳ vọng vào tương lai. Việc tác giả đào sâu vào tâm hồn nhân vật đến từng ngõ ngách thông qua những biện pháp nghệ thuật đã tạo ra loại không gian tâm tưởng. Nắm bắt được những chuyển động và sắc thái tâm trạng nhân vật, Đào Tấn tái hiện nó bằng ngòi bút điêu luyện, với cái nhìn tinh tế. Dòng suy tư của nhân vật tuôn chảy suốt chiều dài tác phẩm diễn ra trong tiềm thức tạo nên một mạch ngầm tâm trạng, một không gian tâm tưởng trải dài, rộng mở với hàng loạt những suy tưởng đan cài, chồng chéo phức tạp.

Trong Hoàng Phi Hổ quá giới bài quan, nỗi đau vì vợ và em gái bị Trụ vương sát hại chưa nguôi, Hoàng Phi Hổ lại tiếp tục đối mặt với nỗi đau phải "khứ quốc ly gia”, "bội quân phản quốc". Trên đường ly hương quá quan, chàng chìm đắm trong tâm trạng u uất "Vì $a i$ chia rẽ đôi đường/Tam cang chẳng trọn ngũ thuoơng lại vong". Đêm xuống ở miếu thần, một mình đối diện với nỗi đau, dòng hồi ức những tháng ngày hạnh phúc tràn về trong niềm tiếc nuối, chàng nhớ đến gia đình, đến vợ con, đến bằng hữu khi xưa quây quần... mà nay tan tác mỗi người một phương:

\section{Thuợng mã đăng cao vọng Giới quan}

Vân mê man, nguyệt hưu mê man

Kim nhật giai vân: ngô phản bạn

Hà thời thức đắc: Trụ hôn quân?

Cố đô cựu vật giai tuoong biệt

Bằng hũu phu thê các nhất phương

Dịch thơ: (Lưng ngựa lên cao ngắm Giới quan

Mây mơ màng, trăng cũng mơ màng

Giờ đây ai cũng: ta làm phản

Nào lúc nhìn ra: Trụ bạo tàn

Đồ xưa vật cũ đều xa cách

Chồng vợ, bạn bè kẻ một phương) 
Dòng hoài niệm xen lẫn sự giày vò trong tư tưởng khi "chưa dứt tình trung với chúa, lòng còn canh cánh khôn nguôi”, rồi đối mặt với nỗi đau khi mất đi người vợ thân yêu của mình, chàng hồi tưởng lại những tháng ngày hạnh phúc bên Giả Thị và chìm đắm trong mộng tưởng: "Tử biệt sinh ly, hưa cưu tuoong tri đồ trướng vọng” (Kẻ chết thì đã mất, người sống lại chia lìa (vậy mà) từ lâu cứ mong mỏi tương tri mãi mãi). Chìm đắm trong dòng tâm tưởng, chàng ngỡ như bị ảo giác khi Giả Thị hiện hồn. Hành động của chàng trở nên điên cuồng khi ôm cái bóng vợ mình trong không khí lạnh lẽo mà đành bất lực, nàng giờ chỉ còn là ảo ảnh khói sương. Hai người giờ thuộc về hai cõi, bị chia lìa bởi nỗi đau sinh ly tử biệt không thể vượt qua được:

Phi Hổ: Ủa này Giả Thị phu nhân! Ha hả...

(Khách) Thậm ủy ngô tâm, em!

\section{(Quăng cây gươm ôm hồn)}

Thùy thức củu nguyên do khả tích

(Lòng ta an ủi biết bao, ai hiểu được người chín suối vẫn còn tiếc nhớ.

(Hồn lại hiện, Hổ lại ôm)

Ná kham kim tịch, anh đây em!

\section{(Lại không thấy hồn)}

Không thành nhất mộng tư hàm sầu

(Đêm nay là đêm gì, bỗng hóa thành giấc mộng tự nuốt lấy sầu)

Không giống như Hoàng Phi Hổ luôn sống trong dòng tâm tưởng hoài niệm quá khứ, Lan Anh lại chìm đắm trong nỗi cô đơn và bế tắc khi đi tìm chồng giữa mênh mông bể trời:

Thư cảnh, thử tình, tâm tụ khổ

Khả nam, khả bắc, lô đa kỳ

\section{Phu quân ôi!}

Hải giác, sonn nhai, lạc lạc cô tung thùy khẳng cố

Thiên cao địa hậu...
Trăm lạy thiên địa quỷ thần, cho tôi gặp phu quân tôi, kẻo mà

Mang mang sầu hận cánh kham bi

(Cảnh ấy tình này lòng những khổ

Khôn dò nam bắc lắm đường đi

Góc biển đầu non, ai kẻ đoái hoài thêm quạnh quẽ

Trời cao đất rộng, hận sầu dày đặc xiết ai bi)

Bủa vây quanh nàng là khó khăn trùng trùng khi thân gái dặm trường bụng mang dạ chửa phiêu bạt tìm chồng nhưng vượt lên tất cả là nỗi lo lắng cho tình cảnh chồng phiêu bạt nơi góc biển chân trời. Nỗi lo lắng thường trực trong tâm khảm đã trở thành sự ám ảnh trong suốt cuộc hành trình của nàng:

Lối sơn khê chi xiết ghập ghình

Tiếng viên điểu càng thêm đau đớn

Phu quân ở! Em ở đây, còn phu quân đi đưò̀ng mô?

Rủi ro sọ đầu tên mũi đạn

Bo' vơ thuơng góc biển chân trời

Từ những diễn biến của tâm trạng nhân vật qua những dòng suy tư, hồi tưởng hay những nỗi ám ảnh thường trực, không gian tâm tưởng hiện ra dưới những sắc màu khác nhau. Nó góp phần đào sâu thêm thế giới nội tâm nhân vật, mở rộng không gian tác phẩm theo chiều hướng nội và kéo thời gian hành động của nhân vật. Đây cũng là một dạng thức không gian nghệ thuật khá phổ biến trong tuồng của Đào Tấn.

Khác với không gian tâm tưởng bị chi phối bởi những quy luật tình cảm, cảm xúc; không gian tâm linh được hình thành từ những vô thức văn hóa, tín ngưỡng, là sản phẩm của trí tưởng tượng và bị chi phối bởi những quy luật hoàn toàn mới lạ mà tri giác của con người cũng không thể biết được. Tôn giáo nào cũng chú trọng vào thế giới tâm linh với niềm tin và 
thêm thắt các phỏng đoán, các tưởng tượng vô cùng hấp dẫn về thế giới đó. Các tôn giáo cũng cho rằng, ngoài không gian vật lý vũ trụ còn có cõi giới siêu hình thiên đường, địa ngục... các cõi giới siêu hình đó tồn tại một cách khách quan giống như không gian vật lý chứa đựng nhiều sinh vật cao cấp như Ngọc Hoàng, các vị thần linh, các loài quỷ sứ yêu ma...

Trầm Hương các mượn cốt truyện Phong thần diễn nghĩa để viết lại, tác phẩm này được Đào Tấn xây dựng thành một không gian tâm linh thần bí đậm chất liêu trai. Một các Trầm Hương thờ Nữ Oa linh thiêng tương thông với cõi tiên giới, bất kì lời nói, hành động nào diễn ra ở các Trầm Hương thì thần Nữ Oa ở cõi tiên đều như đang được chứng kiến. Vì vậy nên khi vua Trụ có những lời nói và hành động suồng sã với bức tượng làm bằng gỗ trầm hương thì cũng như đang trực tiếp ghẹo trêu thần Nữ Oa. Điều đó làm chúng ta liên tưởng, trong thế giới này, các vị thần có năng lực siêu nhiên quảng đại, có thể biết được mọi chuyện trong thiên hạ. Trong thế giới này có Phật, có tiên, có thần và có cả yêu tinh, yêu quái. Con người, thần tiên và yêu ma cùng chung sống với nhau, ảnh hưởng lẫn nhau. Thế giới này cũng có quy luật riêng, có lực lượng thống trị áp chế và sai bảo những thế lực khác. Vậy nên khi "chốn uy linh nhiều tiếng lăng khi" Thần Nữ Oa bèn "chiêu yêu huyền xuất không trung". Hồ Ly, yêu quái bèn trở thành công cụ để trừng phạt cái ác:

Hồ Ly: Phụng chiếu văn, phụng chiếu văn...

(Tẩu) Trực hướng triều Ca, dả diệu thuật tiềm khuynh bạo chúa

Tạ tù đơn phủ, trương tôn linh đắc triển vị tài

(Thẳng tới cung vua, dùng phép lạ diệt trừ bạo chúa
Giã từ điện thánh, dựa oai linh thi thố tài hèn)

Màn đoạt xác Đát Kỷ của Hồ Ly được miêu tả trong một không gian mập mờ tràn đầy yêu khí "Gió ở đâu ngùn ngụt... Đèn trong trướng leo leo", không gian quỷ mị này là bối cảnh thích hợp để hồ ly ra tay đuổi hồn nhập xác "hồn bất định, hồn bất định...nguyện khả thân, nguyện khả thân”. Hồn Đát Kỷ chết đi lại bước vào một thế giới tâm linh khác được Địa tạng đón về cõi hư vô để siêu sinh tịnh độ. Trong thế giới này tiếp tục xuất hiện các nhân vật tâm linh như Phật Như Lai, Quan Âm Bồ Tát, và ở đây Đát Kỷ lại được kể cho biết về một thế giới tâm linh khác, thế giới tiền kiếp của mình là "người hầu duới bẹ đốt hưong lê̂ Phật, bồng sinh thói tuc, nép bên đèn mim cười dâng hoa nên bi đọa xuống trần gian, muời sáu tuổi hoa hòn liễu thẹn" nay "trần duyên dĩ mãn,... đồng quy tịnh độ". Các không gian tâm linh lồng ghép vào nhau, từ thế giới thực sang thế giới ảo, từ trần gian đến thiên đình, thế giới con người đến với thế giới thần tiên, yêu ma cùng tồn tại và gây ảnh hưởng lẫn nhau theo quy luật nhân quả... Có thể nói rằng không gian chính chi phối tuồng bản Trầm Hương các là không gian tâm linh. Trong đó không chỉ có thế giới con người, có thế giới thần phật mà thế giới của yêu tinh, yêu quái cũng được miêu tả một cách sinh động. Đó là thế giới hoang dã, thú tính của quần yêu mà không cách nào che giấu được. Khi Hồ Ly mở yến chiêu mời quần yêu về dự tiệc, Hồ Ly dạy chúng giả tiên nhưng bản chất yêu quái vẫn từ từ được bộc lộ, chúng thích ăn thịt sống, "uống rượu hi ha", nôn mửa khắp nhà và bị lộ cái đuôi yêu quái. Khi bị truy sát, chúng bỏ chạy tán loạn, hiện nguyên hình và chui vào mả để chốn...

Tương tự như Trầm Huoong các, các tuồng bản Sơn hậu, Hộ sinh đàn, Hoàng Phi Hổ quá giới bài quan, Khuê các anh hùng... 
cũng chứa đựng những không gian tâm linh mang đậm màu sắc Phật giáo và tín ngưỡng dân gian. Chính những nét văn hóa riêng biệt này biểu hiện rõ đặc trưng đa hợp của văn hóa dân tộc. Vì vậy mặc dù mượn cốt truyện nước ngoài nhưng các tác phẩm của ông vẫn hết sức gần gũi với người Việt.

Không gian nghệ thuật biểu hiện trong tuồng của Đào Tấn rất phong phú và đa dạng. Cùng với những yếu tố khác của thi pháp nghệ thuật, không gian nghệ thuật là một trong những phương tiện quan trọng để tác giả xây dựng nhân vật, cốt truyện... của tác phẩm.

\section{Thời gian nghệ thuật}

\subsection{Sụ đảo lộn trật tụ tuyến tính thời gian trong tuồng}

Tuồng là loại hình sân khấu tự sự trữ tình phương Đông. Yếu tố tự sự được thể hiện qua lời kể của nhân vật và trật tự tuyến tính thời gian trong tác phẩm. Thời gian trong tuồng cổ là thời gian tuần tự một chiều, sự kiện gì xảy ra trước kể trước, sự kiện gì xảy ra sau kể sau và diễn tiến cho đến hết tác phẩm.

Đối với các tuồng bản do Đào Tấn sáng tác, trật tự của thời gian dường như không còn tuân theo quy luật chung của tuồng truyền thống cũng như những nguyên tắc của sân khấu tự sự. Chúng ta thấy có dấu hiệu đảo lộn trật tự thời gian trong lời kể của nhân vật và sự đồng hiện thời gian - không gian trong cùng một cảnh.

Không giống nhân vật mô thức trong tuồng cổ, nhân vật của Đào Tấn đã "thoát thai” khỏi dạng "nhân vật mặt nạ" quen thuộc của tuồng để hóa thân thành những con người thực có tính cách, tâm hồn và cảm xúc trong tác phẩm. Chính vì vậy, những suy nghĩ, tình cảm của nhân vật không tuân theo mô thức mà tuân theo những quy luật của tư duy, tâm lý. Và dường như nhân vật của Đào Tấn "nghĩ” nhiều hơn là nhân vật "hành động”. Chính trong dòng suy nghĩ ấy, thời gian đã không tuân theo những trật tự thông thường. Trong Diễn võ đình, Triệu Khánh Sanh trên đường trốn chạy khỏi sự truy sát của Bàng Hồng, chàng miên man suy nghĩ về thân phận long đong hiện tại, lại nhớ về những ngày tháng hạnh phúc bên Kiều Quang và hy vọng tương lai có thể "châu về hiệp phố” rồi lại giật mình với thực tại bị truy sát đến nơi:

Khánh sanh: (Tán) Phong cấp viên thanh sầu

\section{Đồ cùng cổ nhân khấp}

Có chũu "Tái ông thất mã tri phi phúc"

Còn sụ tình của tôi bây giò̀, biết khi nào...

Hiệp phố hoàn châu khả dĩ giải uu

(Nam) Xăn tay lần gõ sợi sầu

Tóc lo đã trổ trên đầu hùng anh

Khôn lau nước mắt thwờng tình

Em oi! Nỗi ai ngo ngác nỗi mình bâng khuâng

Tiếng ba quân nghe chùng rộn đến

Hò họ... Giục vó lùa tách dặm sơn khê

Rõ ràng có sự pha trộn giữa hiện tại, quá khứ và tương lai trong suy nghĩ của Khánh Sanh. Thủ pháp đảo ngược thời gian trong suy nghĩ và đồng hiện thời gian để làm nổi bật tâm trạng bế tắc, bi thương của con người được Đào Tấn sử dụng trong hầu hết các phân đoạn độc thoại nội tâm của nhân vật hay tâm sự trên đường cô chinh như Tiết Cương, Hoàng Phi Hổ, Lan Anh, Giả Thị, Đát Kỷ...

Một biểu hiện khác của thời gian đồng hiện là việc tái hiện song hành các hành động, tâm trạng của nhân vật trong cùng một khoảng thời gian. Phương pháp tái hiện này khiến chúng ta liên tưởng tới cách phản ánh đặc trưng của ngôn ngữ điện ảnh. Trong cùng một cảnh thể hiện nhiều không gian và thời gian 
khác nhau với các nhân vật có những hành động, cảm xúc khác nhau, từ đó bao quát được toàn bộ bối cảnh tác phẩm trong một phạm vi rộng. Trong Cổ thành, ngay màn giáo tuồng, ta thấy xuất hiện ba nhân vật ở ba không gian khác nhau cùng bày tỏ suy nghĩ và tâm trạng của mình. Đó là Trương Liêu với khí thế bừng bừng đuổi theo Quan Công:

\section{Mạc nại phong sương phi sất mã}

Bất phân trú da đáo quan thành

Tiết phong mộc võ thiên sơn lộ

Đới nguyệt phi tinh vạn lý trình

(Chẳng nài gió bụi lao thân ngựa

Không quản ngày đêm tới ải quan

Dầm dãi gió mưa ngàn đỉnh núi

Mang sao đội nguyệt vượt muôn trùng)

Còn Quan Vũ lúc đó cũng với khí thế hùng dũng ngút trời chém tướng băng ải với mong muốn sớm nhất đưa hai chị về Cổ thành hội ngộ với đại ca và tam ca:

\section{Cái thế anh hùng mạc dũ kinh}

Phong suoong vạn lý triển bằng trình

Ngũ quan trục quá phò xa trương

Sơn hải gian nguy nhwợc lý bình

(Dưới thế anh hùng dễ mấy ai

Gió sương muôn dặm cánh chim trời

Xông pha năm ải phò hai chị

Đạp núi san bằng mọi hiểu nguy)

Cũng trong thời gian ấy, Hạ Hầu Đôn cũng đang trấn ải chờ Quan Vũ bằng một khí thế oai phong, hùng dũng:

Ngang ngang khí khái dục lăng tiêu

Khả hiệp thái sơn bắc hải siêu

Thế thuợng vô song, chiến địa thùy năng tài lực địch?

Nhân gian đệ nhật, họa đài ung cộng tánh danh bêu

(Khí khái hiên ngang muốn vượt lên trời thẳm
Cắp nách hòn núi Thái vượt qua bể bắc

Trên đời không có hai, trên chiến trường ai là kẻ đủ sức đối chọi

Trong nhân gian ta là bậc nhất, tên tuổi đáng nêu chung với các tướng giỏi đời xưa)

Cách kết cấu ba hồi ngắn liên tiếp chỉ bao gồm lời tự bạch của ba nhân vật trong ba khung cảnh khác nhau là sự đồng hiện thời gian trên bề mặt văn bản. Do giới hạn tuyến tính của ngôn ngữ, Đào Tấn dùng các hồi ngắn để chuyển không gian liên tục như những tia cắt chớp nhoáng để diễn tả ba không gian cùng xảy ra trong một thời gian. Thông thường trong tuồng, các nhân vật chỉ đối thoại trực tiếp trong cùng một không gian, thời gian chứ hiếm khi diễn tả ba không gian khác nhau trong một thời gian. Đây là một trong những cách tân đáng kể về mặt sân khấu của Đào Tấn. Việc miêu tả ba nhân vật với tài năng tuyệt đỉnh khí thế hùng cường đồng hiện trong một thời gian khiến chúng ta dự đoán được sự gặp gỡ của ba nhân vật này sẽ có những biến cố không ngờ. Điều đó tạo sự lôi cuốn, hấp dẫn đối với người xem tuồng và cũng làm cho sân khấu tuồng chân thực và sinh động hơn.

Việc đồng hiện thời gian còn được Đào Tấn sử dụng khi miêu tả tâm trạng của những nhân vật cặp đôi như: Lan Anh - Tiết Cương, Khánh Sanh - Kiều Quang, Hoàng Phi Hổ Giả Thị. Các cặp đôi này đều phải chịu cảnh ân ái chia ly, tâm trạng buồn, nhớ thương khắc khoải đều được thể hiện qua suy nghĩ và độc thoại nội tâm. Việc đồng hiện thời gian giúp người đọc đối chiếu tâm trạng của hai nhân vật khiến nỗi đau như được nhân hai, sức mạnh truyền cảm mạnh mẽ hơn rất nhiều lần.

\section{tâm linh}

3.2. Thò̀i gian tâm tưởng và thò̀i gian

Thời gian tâm tưởng và thời gian tâm linh trong tuồng đều bị chi phối bởi quan niệm cá nhân và mang tính ước lệ. 
Trong văn học trung đại nói chung và trong tuồng nói riêng, con người thường có xu hướng muốn làm chủ thời gian hay nói cách khác thời gian thường được phản ánh qua lăng kính chủ quan của con người. Do vậy thời gian tâm tưởng thường có sự khác biệt khá lớn so với thời gian thực tế. Quy luật "ngày vui ngắn chẳng tày gang" chi phối cảm quan về thời gian của hầu hết các nhân vật trong tuồng. Trong hoàn cảnh chia ly, các nhân vật đều có xu hướng hoài niệm về những tháng ngày hạnh phúc và cảm nhận khoảng thời gian đó thật ngắn ngủi, kèm theo đó là những tiếc nuối khôn nguôi. Đó là tâm trạng Hoàng Phi Hổ Giả Thị trong phút hàn huyên ngắn ngủi tại miếu thần, tâm trạng của Khánh Sanh - Kiều Quang lúc chia tay tiễn Khánh Sanh lên đường trốn chạy sự truy đuổi của Bàng Hồng, tâm trạng Tiết Cương - Lan Anh sau lần hội ngộ thứ nhất tại Long Sơn trại. Sự đối lập giữa "ngày vui thì ngắn ngủi" còn những ngày chia xa thì dài dằng dặc bị chi phối bởi tình cảm và cảm xúc của con người. Đứng trước đau buồn, đứng trước nỗi cô đơn, con người thường có xu hướng chìm đắm vào trong đó và tự huyễn hoặc mình. Vì thế thời gian tâm tưởng đôi khi được biểu hiện bằng thời gian huyền ảo với cặp đối lập "xưa sao... nay sao..” hoặc "bao giờ... như xưa":

\section{“Ngày ngày lặn suối trèo non}

Bao giờ cho đặng vuông tròn nhur xua",

Thời gian tâm tưởng thường xuất hiện vào lúc "vầng ô khuất núi”, "bóng tà" hay “trăng tàn”, "bóng ác hầu chênh" là những thời điểm gợi buồn trong thơ văn cổ.

Thời gian tâm linh là thời gian gắn với sự xuất hiện của các yếu tố tâm linh trong tác phẩm. Thời điểm được chọn để xuất hiện các yếu tố tâm linh thường là đêm tối, chạng vạng hoặc rạng sáng. Đó là những thời điểm vượng âm khí hoặc thời khắc giao nhau giữa ngày và đêm. Đát Kỷ bị đoạt hồn khi “đã khuya khoắt ỷ khôn làm tỉnh”, Linh Tá xuất hiện soi đường giữa đêm tối mịt mùng, Giả Thị hiện hồn khi Hoàng Phi Hổ đang ngủ bỗng thấy "Gió phút động bên màn/ Kìa tay ai cầm đuốc?”...

Thời gian tâm linh có thể làm ta quên đi sự khác biệt trong hiện thực vì nó tiếp nối hiện thực, nhập làm một với thời gian trong hiện thực hoặc là một phần của hiện thực. Do đặc trưng của sân khấu truyền thống Việt Nam là tự sự - trữ tình, diễn tiến các sự kiện diễn ra theo một chiều, các sự kiện tiếp nối nhau xuất hiện theo thời gian một cách tuần tự nên thời gian thực và thời gian tâm linh xen kẽ nối tiếp nhau. Sự chuyển biến thời gian trong tuồng rất nhanh, chỉ qua lời thuật của nhân vật mà ta có thể đi từ không gian này sang không gian khác, từ thời gian thực đến thời gian tâm linh trong nháy mắt.

Thời gian tâm linh trong tuồng có những nhịp điệu, sắc độ riêng để phản ánh hiện thực. Yếu tố tâm linh xuất hiện trong tuồng thường mang một ý nghĩa nhất định nên chứa đựng trong đó khoảng sâu văn hóa cần diễn giải. Vì vậy thời gian tâm linh cũng có thể được rút ngắn trong một câu trần thuật hay kéo dài bằng cách miêu tả rất tỉ mỉ mọi diễn biến tâm trạng, mọi diễn biến hành động của nhân vật, các sự kiện hoặc nhấn nhá trong câu ca, lời hát. Khương Linh Tá hiện hồn soi đèn cho Kim Lân cả đêm nhưng thời gian hiện hồn được nén đọng trong một câu trần thuật. Giả Thị hiện hồn than khóc với chồng trong chốc lát nhưng tâm tư tình cảm dãi bày đến cả lớp tuồng. Thời gian tâm linh là biểu hiện sinh động của thời gian nghệ thuật trong tuồng.

Như vậy có thể thấy, không gian và thời gian nghệ thuật trong kịch bản tuồng Đào Tấn cũng chịu sự chi phối của cảm thức không gian thời gian trong văn học cổ trung đại như không gian khuê phòng, không gian quan ải, thời gian 
tâm tưởng... Bên cạnh đó, ông có những cách tân đáng kể khi sử dụng đa dạng các kiểu không gian, thời gian tâm linh để biểu hiện đời sống tinh thần phong phú của con người. Đặc biệt là sự đảo lộn trật tự tuyến tính của thời gian, sử dụng linh hoạt không gian hành trình và sự đồng hiện nhiều không gian thời gian trong cùng một cảnh đã đem lại những hiệu quả nghệ thuật độc đáo cho kịch bản tuồng của ông. Với những cách tân mạnh mẽ về nội dung cũng như nghệ thuật, Đào Tấn xứng đáng là bậc thầy của văn chương tuồng, là nhà biên kịch tuồng xuất sắc nhất mọi thời đại, là "Hậu tổ nghề tuồng" của Việt Nam.

\section{TÀI LIỆU THAM KHẢO}

1. Hoàng Chương (Chủ biên - 2008), Đào Tấn - trăm năm nhìn lại, Nxb Hội Nhà văn, Hà Nội;

2. Dương Quảng Hàm (1941), Việt Nam văn học sủ yếu, Nxb Đông Pháp, Hà Nội;

3. Hoàng Châu Ký (1978), Tuồng cổ (tập 1), Nxb Văn hóa, Hà Nội;

4. Vũ Ngọc Liễn (2005), Đào Tấn tuồng hát bội, Nxb Sân khấu, Hà Nội;

5. Mịch Quang (1963), "Bàn về một vài đặc điểm của văn học tuồng", Văn học, (6), tr. 51 - 63

6. Trần Đình Sử (1993), Giáo trình thi pháp học, Nxb Đại học Sư phạm Thành phố Hồ Chí Minh, TPHCM;

7. Trần Đình Sử (1999), Mấy vấn đề Thi pháp văn học trung đại Việt Nam, Nxb Giáo dục, Hà Nội, Nxb Đại học Quốc gia, Hà Nội. 